SHORT REPORT

\title{
The mitochondrial superoxide dismutase Al6V polymorphism in the cardiomyopathy associated with hereditary haemochromatosis
}

\author{
L Valenti, D Conte, A Piperno, P Dongiovanni, A L Fracanzani, M Fraquelli, A Vergani, C Gianni, \\ L Carmagnola, S Fargion
}

The A16V mitochondrial targeting sequence polymorphism influences the antioxidant activity of MnSOD, an enzyme involved in neutralising iron induced oxidative stress. Patients with hereditary haemochromatosis develop parenchymal iron overload, which may lead to cirrhosis, diabetes, hypogonadism, and heart disease. The objective of this study was to determine in patients with haemochromatosis whether the presence of the Val MnSOD allele, associated with reduced enzymatic activity, affects tissue damage, and in particular heart disease, as MnSOD knockout mice develop lethal cardiomyopathy. We studied 217 consecutive unrelated probands with haemochromatosis, and 212 healthy controls. MnSOD polymorphism was evaluated by restriction analysis. The frequency distribution of the polymorphism did not differ between patients and controls. Patients carrying the $\mathrm{Val}$ allele had higher prevalence of cardiomyopathy (A/A 4\%, A/V 11\%, V/V 30\%, p=0.0006) but not of cirrhosis, diabetes, or hypogonadism, independently of age, sex, alcohol misuse, diabetes, and iron overload (odds ratio 10.1 for $V / V, p=0.006$ ). The frequency of the Val allele was higher in patients with cardiomyopathy $(0.67 v 0.45, p=0.003)$. The association was significant in both $\mathrm{C} 282 \mathrm{Y}+/+(p=0.02)$, and in non-C282Y+/+ patients $(p=0.003)$, and for both dilated $(p=0.01)$ and non-dilated stage $(p=0.04)$ cardiomyopathy, but not for ischaemic heart disease. In patients with hereditary haemochromatosis, the MnSOD genotype affects the risk of cardiomyopathy related to iron overload and possibly to other known and unknown risk factors and could represent an iron toxicity modifier gene.

$\mathrm{H}$ ereditary haemochromatosis $(\mathrm{HH})$, the most common autosomal recessive disease in white populations, is characterised by progressive iron overload with development of cirrhosis, diabetes, arthritis, hypogonadism, and cardiomyopathy. ${ }^{12}$ In the majority of cases, $\mathrm{HH}$ is related to homozygosity for the C282Y mutation of the HFE gene, ${ }^{3}$ but the penetrance is not complete, and population studies indicate that full blown clinical expression occurs in only $1-25 \%$ of C282Y homozygotes. ${ }^{4-7}$ Inherited factors have been suggested to influence the phenotype, but genes involved in iron metabolism do not seem to play a major role. ${ }^{8-10}$

Iron toxicity is mediated by oxidative damage, which results in mitochondrial injury. ${ }^{11}{ }^{12}$ Manganese mitochondrial superoxide dismutase (MnSOD or SOD2) catalyses the removal of superoxide at its site of production, the matrix side of the inner mitochondrial membrane. Increased iron concentration induces MnSOD expression, and overexpression of MnSOD prevents iron related oxidative damage. ${ }^{13}{ }^{14}$ Moreover, mice in which the MnSOD gene has been knocked out develop neonatally lethal cardiomyopathy and fatty liver. ${ }^{15}$ The enzyme is encoded by nuclear DNA, and synthesised with a mitochondrial targeting sequence. A number of polymorphisms in this sequence have been described, but only Ala16Val has been demonstrated to have a functional significance. ${ }^{16-18}$ The Val allele, by disrupting the $\alpha$-helix structure of the protein, which is important for the translocation of the enzyme to the mitochondrial matrix where it exerts its function, causes the protein to be retained at the level of the mitochondrial inner membrane and has been associated with 30-40\% lower activity compared with the Ala allele, and to increased susceptibility to oxidative stress. $^{18}$

Hypothesising that MnSOD influences iron toxicity, we analysed the prevalence of the Al6V polymorphism and its correlation with iron induced organ damage, especially cardiomyopathy, in a series of Italian patients with HH.

\section{METHODS \\ Patients}

We enrolled 217 consecutive unrelated probands with $\mathrm{HH}$, $199(92 \%)$ of whom were from northern, and 18 (8\%) from southern Italy. The diagnosis ${ }^{1}{ }^{19}$ was based on the presence of a phenotype compatible with $\mathrm{HH}$ (iron removed to reach iron depletion $>5 \mathrm{~g}$ in males, $>3 \mathrm{~g}$ females; hepatic iron index ${ }^{20}$ $>1.9$; typical parenchymal siderosis), in the absence of secondary causes of iron overload. Patients with juvenile $\mathrm{HH}$ were excluded from this study. All patients were referred because of iron overload and/or liver disease. Available clinical data at diagnosis included: age, sex, presence of alcohol misuse $(>60$ or $40 \mathrm{~g} /$ day in men and women, respectively, for $>5$ years), hepatitis $\mathrm{B}$ virus (HBV) surface antigen, anti-hepatitis C virus (HCV) antibodies, HCV RNA status, serum alanine aminotransferase, ferritin and transferrin saturation at diagnosis, amount of iron removed to reach depletion, HFE gene mutations, the presence of cirrhosis (histologically proven), diabetes (WHO criteria), hypogonadism (clinical and biochemical diagnosis), arthritis (clinical and radiological diagnosis), ${ }^{21}$ and cardiomyopathy. ${ }^{22-24}$ Mutations in the coding sequences of the transferrin receptor-2 and ferroportin-1 genes ${ }^{25}{ }^{26}$ were excluded in all of the non-C282Y+/+ patients. Cardiomyopathy stage was further classified as dilated ${ }^{22}$ (increased ventricular size (left ventricular end diastolic diameter $>56 \mathrm{~mm}$ ) and decreased systolic function (ejection fraction $<50 \%)$ ), non-dilated (restrictive cardiomyopathy, ${ }^{23}$ increased interventricular

Abbreviations: $\mathrm{HBV}$, hepatitis $\mathrm{B}$ virus; $\mathrm{HCV}$, hepatitis $\mathrm{C}$ virus; $\mathrm{HH}$, hereditary haemochromatosis; MnSOD, manganese mitochondrial superoxide dismutase 
septum thickness (>11 mm), and/or altered ultrasonographic structure, presence of conduction defects), or associated with ischaemic heart disease (previous myocardial infarction and/or ultrasonographic/electrocardiographic/ angiographic evidence of regional ischaemia).

Mean (SD) age was 48.7 (12) years; 47 patients (22\%) were females; 144 patients (66\%) were C282Y homozygotes, ${ }^{27}$ and $14(6 \%)$ were $\mathrm{C} 282 \mathrm{Y} / \mathrm{H} 63 \mathrm{D}$ compound heterozygotes; 28 (13\%) had coexistent chronic viral hepatitis; and 37 (18\%) were alcohol misusers. Mean (SD) serum ferritin at diagnosis was 1731 (1702) ng/ml (reference values: men $<320$, women $<240 \mathrm{ng} / \mathrm{ml}$ ), transferrin saturation $78.8(21) \%$ (men $<45 \%$, women $<40 \%)$, iron removed to reach depletion 8.65 (7) g $(<3 \mathrm{~g})$, alanine aminotransferase 58.2 (54) U/l (<40 U/l). There were 92 patients (42\%) with cirrhosis, and 43 (19\%) had diabetes, 48 (22\%) arthritis, 42 (19\%) hypogonadism, and $27(12 \%)$ cardiomyopathy.

\section{Controls}

The control group comprised 212 healthy blood donor subjects: 194 (92\%) from northern, and $18(8 \%)$ from central and southern Italy, without evidence of iron overload, liver disease, diabetes, or heart disease; the latter was excluded on the basis of clinical, electrocardiographic, and (when indicated) echocardiographic findings. There were 41 women $(19 \%)$, and mean (SD) age was 44.7 (11) years. Serum ferritin was normal in all but three cases (male subjects; ferritin <450, 415, and $380 \mathrm{ng} / \mathrm{ml}$ ). HFE genotypes were $\mathrm{C} 282 \mathrm{Y} / \mathrm{wt}$ in 5 cases (2\%), H63D/H63D in 7 (3\%), H63D/wt in $49(23 \%)$, and wt/wt in $151(72 \%)$. Informed written consent was obtained for each subject included in this study. MnSOD genotype was evaluated by restriction analysis ${ }^{17}$ following validation of the method by sequencing.

Results were expressed as mean (SD). A two tailed value of $\mathrm{p}<0.05$ was considered significant. Data were compared by $t$ test, and frequencies by Fisher's exact test; $\chi^{2}$ for trend was applied when comparing frequencies betwen $\mathrm{A} / \mathrm{A}, \mathrm{A} / \mathrm{V}$, and $\mathrm{V} / \mathrm{V}$ MnSOD genotypes. Logistic regression analyses were performed both to adjust $M n S O D$ polymorphism frequency distribution for age, sex, and geographical origin in patients versus controls, and to assess the relationship between $M n S O D$ genotypes and $\mathrm{HH}$ related complications (independent variables considered are shown where appropriate).

\section{RESULTS}

The frequency distribution of the MnSOD polymorphisms was not significantly different between patients and controls (table 1).

\begin{tabular}{|c|c|c|c|}
\hline & \multicolumn{3}{|c|}{ MnSOD genotype, n (\%) } \\
\hline & A/A & $A / V$ & $\mathrm{~V} / \mathrm{V}$ \\
\hline $\begin{array}{l}\mathrm{HH}(n=217) \\
\text { Controls } \\
(\mathrm{n}=212)\end{array}$ & $\begin{array}{l}48(23) \\
43(20)\end{array}$ & $\begin{array}{l}132(60) \\
118(56)\end{array}$ & $\begin{array}{l}37(17) \\
51(24)\end{array}$ \\
\hline $\begin{array}{l}\text { OR for } \mathrm{HH} \\
95 \% \mathrm{Cl}\end{array}$ & 1 (RV) & $\begin{array}{l}1.1 \\
0.7 \text { to } 1.8\end{array}$ & $\begin{array}{l}0.7 \\
0.4 \text { to } 1.2\end{array}$ \\
\hline
\end{tabular}

Odds ratio (OR) for haemochromatosis; logistic regression analysis adjusted for age, sex, and geographical origin (northern Italy versus others). RV, reference value; $\mathrm{Cl}$, confidence interval; $\mathrm{HH}$, hereditary haemochromatosis; $\mathrm{A} /$ $A$, homozygosity for the Ala allele; $A / V$, heterozygosity for Ala and Val alleles; V/V, homozygosity for the Val allele.
Demographic features, the proportion of C282Y homozygous subjects, the degree of iron overload, the prevalence of alcohol misuse, coexistent chronic viral hepatitis, cirrhosis, diabetes, arthropathy, and hypogonadism were not significantly different when patients were subdivided according to MnSOD genotypes (table 2). This was true for the overall series of patients, for subjects with different $H F E$ genotypes $(\mathrm{C} 282 \mathrm{Y}+/+$ and non-C282Y+/+), and after excluding from the analysis those with acquired risk factors (HBV/HCV infection, alcohol misuse). MnSOD genotypes containing the Val allele were associated with cardiomyopathy (A/A 2/48, 4\%; A/V $14 / 132,11 \%$; V/V 11/37, 30\%, p=0.0006), the prevalence of the Val allele being 0.67 in patients with cardiomyopathy and 0.45 in those without $(p=0.003)$. Moreover, the frequency of the Val allele was significantly higher in patients with cardiomyopathy compared with control subjects $(0.67 v 0.52$; $\mathrm{p}=0.04)$, and significantly lower in patients without cardiomyopathy than in controls $(0.45 v 0.52 ; \mathrm{p}=0.048)$. No significant difference in the prevalence of the Val allele was observed in patients subdivided according to the presence of cirrhosis, diabetes, arthropathy, and hypogonadism. The prevalence and type of cardiomyopathy in patients subdivided according to $H F E$ and MnSOD genotypes are shown in table 3. A/V and $\mathrm{V} / \mathrm{V}$ genotypes were associated with either dilated (ejection fraction $41(7) \%)$, or non-dilated stage cardiomyopathy $\left(p=0.01\right.$ and $p=0.04$ respectively at $\chi^{2}$ for trend), but not with ischaemic related cardiomyopathy. Even after exclusion of subjects with coexistent hepatitis virus infection, MnSOD genotypes containing the Val allele were associated with cardiomyopathy in both C282Y (A/A 2/27, 7\%; $\mathrm{A} / \mathrm{V} 10 / 82,12 \% ; \mathrm{V} / \mathrm{V}$ 8/26, 31\%; $\mathrm{p}=0.017)$ and nonC282Y homozygotes (A/A 0/11; A/V 2/35, 6\%; V/V 3/8, 38\%; $\mathrm{p}=0.009$ ).

The prevalence of hypertension was 7/27 (26\%) in patients with cardiomyopathy, not significantly different between the different types of heart disease or from that of patients without heart disease. Demographic, genetic, and clinical features of the 27 patients with $\mathrm{HH}$ and cardiopathy included in this study are shown in table 4.

Table 2 Demographic and clinical features at diagnosis of 217 patients with hereditary haemochromatosis subdivided on the basis of their MnSOD genotype

\begin{tabular}{|c|c|c|c|}
\hline & \multicolumn{3}{|c|}{ MnSOD genotype } \\
\hline & $A / A(n=48)$ & $A / V(n=132)$ & $V / V(n=37)$ \\
\hline Female sex & $10(21 \%)$ & $28(21 \%)$ & $9(24 \%)$ \\
\hline Age (years) & 49 (13) & 48.1 (12) & $50.6(13)$ \\
\hline \multicolumn{4}{|l|}{ HFE } \\
\hline $\mathrm{C} 282 \mathrm{Y} / \mathrm{C} 282 \mathrm{Y}$ & $29(60 \%)$ & $87(66 \%)$ & $28(76 \%)$ \\
\hline $\mathrm{C} 282 \mathrm{Y} / \mathrm{H} 63 \mathrm{D}$ & $3(6 \%)$ & $9(7 \%)$ & $2(5 \%)$ \\
\hline $\mathrm{C} 282 \mathrm{Y} / \mathrm{wt}$ & $3(6 \%)$ & $4(3 \%)$ & - \\
\hline H63D/H63D & $4(8 \%)$ & $3(2 \%)$ & $1(3 \%)$ \\
\hline TfR2 / ferroportin & - & - & - \\
\hline \multicolumn{4}{|l|}{ mutations } \\
\hline Alcohol misuse & $8(17 \%)$ & $24(18 \%)$ & $5(13 \%)$ \\
\hline Ferritin (ng/ml) & $1899(2157)$ & $1713(1636)$ & $1591(1288)$ \\
\hline Transferrin saturation (\%) & $81(21)$ & $77(21)$ & $82.6(18)$ \\
\hline $\begin{array}{l}\text { Iron removed to } \\
\text { depletion (g) }\end{array}$ & $9.4(7)$ & $8.5(6.9)$ & $8.2(7.9)$ \\
\hline $\begin{array}{l}\mathrm{HCV} / \mathrm{HBV} \text { chronic } \\
\text { hepatitis }\end{array}$ & $8(17 \%)$ & $17(13 \%)$ & $3(8 \%)$ \\
\hline ALT & 56146 & $61(59)$ & $50(37)$ \\
\hline Liver cirrhosis & $21(44 \%)$ & $53(40 \%)$ & $18(49 \%)$ \\
\hline Diabetes & $7(14 \%)$ & $26(20 \%)$ & $10(27 \%)$ \\
\hline Arthropathy & $11(23 \%)$ & $25(21 \%)$ & $12(32 \%)$ \\
\hline Hypogonadism & $11(23 \%)$ & $23(17 \%)$ & $8(22 \%)$ \\
\hline Cardiomyopathy & $2^{*}(4 \%)$ & $14^{*}(11 \%)$ & $11 *(30 \%)$ \\
\hline
\end{tabular}


Table 3 Prevalence and type of cardiomyopathy (dilated and non-dilated stage, and associated with ischaemic heart disease) in 217 patients with hereditary haemochromatosis, according to HFE status and MnSOD genotype

\begin{tabular}{|c|c|c|c|c|c|c|}
\hline \multirow[b]{2}{*}{ HFE status } & \multirow[b]{2}{*}{$\begin{array}{l}\text { MnSOD } \\
\text { genotype }\end{array}$} & \multirow[b]{2}{*}{$\mathbf{n}$} & \multicolumn{4}{|c|}{ Cardiomyopathy, n } \\
\hline & & & Overall & Dilated & $\begin{array}{l}\text { Non- } \\
\text { dilated }\end{array}$ & Ischaemic \\
\hline \multirow[t]{3}{*}{$C 282 Y+/+(n=144)$} & $\mathrm{A} / \mathrm{A}$ & 29 & $2^{*}(7 \%)$ & 0 & 1 & 1 \\
\hline & $\mathrm{A} / \mathrm{V}$ & 87 & $12 *(14 \%)$ & 4 & 5 & 3 \\
\hline & $\mathrm{V} / \mathrm{V}$ & 28 & $8^{*}(29 \%)$ & 3 & 4 & 1 \\
\hline \multirow{3}{*}{ Non-C282Y $+/+(n=73)$} & $A / A$ & 19 & $0 t$ & $0 \ddagger$ & 0 & 0 \\
\hline & $A / V$ & 45 & $2+(4 \%)$ & $1 \ddagger$ & 1 & 0 \\
\hline & $\mathrm{V} / \mathrm{V}$ & 9 & $3+(33 \%)$ & $2 \ddagger$ & 1 & 0 \\
\hline
\end{tabular}

Using logistic regression analysis that considered age (years), sex, iron removed to reach depletion (g), the presence of diabetes and of alcohol misuse, and MnSOD genotype (A/A and $\mathrm{A} / \mathrm{V}$ versus $\mathrm{V} / \mathrm{V})$ as independent variables, cardiomyopathy was significantly associated with iron removed $(\mathrm{p}=0.005$; odds ratio $1.09 ; 95 \%$ confidence interval 1.03 to 1.15$)$, age $(\mathrm{p}=0.006 ; 1.07 ; 1.02$ to 1.1$)$, and $\mathrm{V} / \mathrm{V}$ genotype $(p=0.006 ; 10.1,2$ to 54$)$. The $p$ value for the $\chi^{2}$ model was $<0.001$.

\section{DISCUSSION}

In this study, we assessed whether a genetic variant of MnSOD, affecting detoxification of reactive oxygen species, influences iron induced tissue damage in patients with $\mathrm{HH}$. Our results indicate that, independently of the degree of iron overload and the genetic background, the Val allele, previously linked to impaired enzymatic activity, is strongly associated with the presence of cardiomyopathy.
We considered a large and well characterised population of unrelated Italian patients with $\mathrm{HH}$, comprising both $\mathrm{C} 282 \mathrm{Y}+/+$ subjects and patients with non HFE-related haemochromatosis, ${ }^{27}$ fully representative of subjects who come to clinical attention in the Milan area, in whom the presence of organ involvement has systematically been assessed by reference methods.

Even after correction for age, sex, and geographical origin, the frequency distribution of the MnSOD polymorphism did not differ between patients and healthy controls, in whom it was in Hardy-Weinberg equilibrium. The degree of iron overload was not different among patients grouped according to MnSOD genotypes, consistent with a lack of effect of MnSOD on iron absorption. In contrast, Livesey et al recently suggested that a mitochondrial DNA mutation affecting mitochondrial redox status influences iron overload in C282Y+/+ subjects. ${ }^{28}$ However, it should be noted that these authors analysed the effect of the mitochondrial DNA genotype on the expression of iron overload in $\mathrm{C} 282 \mathrm{Y}+/+$

\begin{tabular}{|c|c|c|c|c|c|c|c|}
\hline No. & Age & Sex & HFE & MnSOD & $\begin{array}{l}\text { Cardiological } \\
\text { diagnosis }\end{array}$ & $\begin{array}{l}\text { Iron } \\
\text { removed (g) }\end{array}$ & $\begin{array}{l}\text { Associated } \\
\text { factors }\end{array}$ \\
\hline 1 & 64 & M & $282+/+$ & $\mathrm{V} / \mathrm{V}$ & NDCM & 7 & - \\
\hline 2 & 43 & M & $282+1+$ & $\mathrm{V} / \mathrm{V}$ & NDCM & 16 & Diabetes \\
\hline 3 & 46 & M & $282+1+$ & $\mathrm{V} / \mathrm{V}$ & DCM & 44 & Diabetes \\
\hline 4 & 68 & $\mathrm{~F}$ & $282+1+$ & $V / V$ & DCM & 7 & - \\
\hline 5 & 57 & $\mathrm{~F}$ & $282+1+$ & $\mathrm{V} / \mathrm{V}$ & IHD & 10 & Hypertension \\
\hline 6 & 33 & M & $282+1+$ & $\mathrm{V} / \mathrm{V}$ & DCM & 5 & Alcohol misuse \\
\hline 7 & 59 & M & $282+/+$ & $\mathrm{V} / \mathrm{V}$ & NDCM & 5 & - \\
\hline 8 & 82 & $\mathrm{~F}$ & $282+/+$ & $\mathrm{V} / \mathrm{V}$ & NDCM & 8 & - \\
\hline 9 & 49 & M & wt/wt & $\mathrm{V} / \mathrm{V}$ & DCM & 12 & $\begin{array}{l}\text { Diabetes, } \\
\text { hypertension }\end{array}$ \\
\hline 10 & 50 & M & $w t / 63$ & $\mathrm{~V} / \mathrm{V}$ & DCM & 3 & - \\
\hline 11 & 66 & M & wt/wt & $\mathrm{V} / \mathrm{V}$ & NDCM & 10 & Alcohol misuse \\
\hline 12 & 36 & $M$ & $282+/+$ & $\mathrm{A} / \mathrm{V}$ & DCM & 22 & $\begin{array}{l}\text { Dyslipidaemia, } \\
\text { hypertension }\end{array}$ \\
\hline 13 & 41 & M & $282+/+$ & $\mathrm{A} / \mathrm{V}$ & NDCM & 12 & - \\
\hline 14 & 53 & $\mathrm{~F}$ & $282+/+$ & $A / V$ & DCM & 21 & - \\
\hline 15 & 51 & M & $282+/+$ & $A / V$ & NDCM & 39 & Diabetes \\
\hline 16 & 72 & $\mathrm{~F}$ & $282+/+$ & $A / V$ & NDCM & 4 & - \\
\hline 17 & 52 & M & $282+/+$ & $A / V$ & IHD & 8 & Hypertension \\
\hline 18 & 56 & M & $282+/+$ & $A / V$ & DCM & 10 & Diabetes \\
\hline 19 & 69 & $M$ & $282+/+$ & $\mathrm{A} / \mathrm{V}$ & $\mathrm{IHD}$ & 8 & $\begin{array}{l}\text { Diabetes, } \\
\text { hypertension }\end{array}$ \\
\hline 20 & 67 & M & $282+/+$ & $A / V$ & DCM & 4 & - \\
\hline 21 & 55 & M & $282+/+$ & $A / V$ & NDCM & 6 & Diabetes \\
\hline 22 & 69 & $\mathrm{~F}$ & $282+1+$ & $\mathrm{A} / \mathrm{V}$ & NDCM & 4 & Diabetes \\
\hline 23 & 59 & $\mathrm{~F}$ & $282+/+$ & $A / V$ & IHD & 5 & Hypertension \\
\hline 24 & 68 & $M$ & wt/wt & $\mathrm{A} / \mathrm{V}$ & DCM & 7 & Alcohol misuse \\
\hline 25 & 57 & $\mathrm{~F}$ & wt/wt & $A / V$ & NDCM & 25 & - \\
\hline 26 & 38 & M & $282+/+$ & $\mathrm{A} / \mathrm{A}$ & NDCM & 23 & Diabetes \\
\hline 27 & 55 & M & $282+/+$ & $\mathrm{A} / \mathrm{A}$ & $\mathrm{HD}$ & 5 & $\begin{array}{l}\text { Alcohol misuse, } \\
\text { hypertension }\end{array}$ \\
\hline
\end{tabular}


subjects, while our aim was to determine whether, independently from the genetic defect underlying $\mathrm{HH}, \mathrm{MnSOD}$ genotype affects the organ damage related to iron overload.

In patients with $\mathrm{HH}$, the Val allele, (which confers $30-40 \%$ decreased enzymatic activity and superoxide detoxification, because of the impaired transport of the resultant protein across the inner mitochondrial membrane ${ }^{18}$ ), was associated with the presence of cardiomyopathy, both dilated and nondilated. The 16Val allele was significantly more prevalent in patients with heart disease compared both with those without disease and with the control subjects, while subjects without cardiomyopathy had a significantly lower frequency of the Val allele compared with controls. The presence of the Val allele was not associated with ischaemic heart disease, in the pathogenesis of which the role of iron is still controversial. ${ }^{29}{ }^{30}$ Moreover, the Val/Val genotype conferred a 10 fold increased risk of heart disease, independently of confounding factors (age, sex, alcohol misuse, diabetes, and iron overload; the latter, as previously reported, ${ }^{22}$ strongly associated with the risk of heart disease).

As $\mathrm{HH}$ is a heterogeneous disease in Italy, and different genetic defects may influence iron overload and tissue iron distribution, we analysed the effect of $M n S O D$ genotype in $\mathrm{C} 282 \mathrm{Y}+/+$ and non-C282Y+/+ subjects. The association between the Val allele and cardiomyopathy was significant in both the genetically homogeneous group of C282Y homozygotes, and in the non-C282Y homozygotes, even after exclusion of patients with chronic viral hepatitis (potentially affecting liver disease and iron overload), suggesting that the decreased MnSOD activity in patients with a phenotype compatible with $\mathrm{HH}$ increases the risk of heart injury independently of the genetic defect responsible for iron overload, and the associated acquired factors.

Experimental data indicate that increased MnSOD activity prevents iron induced oxidative damage, ${ }^{16}$ and knockout $M n S O D$ mice develop dilated cardiomyopathy, ${ }^{15}$ which is neonatally lethal, probably due to the critically high mitochondrial concentration and oxygen tension in the heart. Interestingly, it has recently been reported that HFE - / - mice develop cardiac iron overload with increased reactive oxygen species content and decreased MnSOD activity, and are at increased susceptibility to oxidative damage. ${ }^{31}$ However, as MnSOD-/+ mice do not develop heart disease, it is possible that a partial defect in MnSOD activity becomes clinically significant in the presence of iron overload or other factors able to induce oxidative stress. Similarly, Val/ Val control subjects are very probably not at increased risk of cardiomyopathy in the absence of a triggering factor. However, Hiroi et $a l^{32}$ have reported a twofold increase in the risk of idiopathic dilated cardiomyopathy in subjects carrying the MnSOD 16Val/Val genotype, associated with a decreased processing of the MnSOD leader peptide, raising the possibility that it plays a role, even if smaller, also in the general population.

In conclusion, the functional Al6V MnSOD polymorphism affects the risk of cardiomyopathy related to iron overload and possibly to other known and unknown risk factors, and may represent an iron toxicity modifier. Whether the $M n S O D$ genotype influences the development of heart disease in transfusion dependent patients with secondary iron overload and the iron related myocardial toxic effects of antracyclines, ${ }^{33} 34$ and interacts with DNA mitochondrial variants, ${ }^{26}$ warrants further investigation. It would be also interesting to assess whether HFE and MnSOD genotypes interact in determining the risk of cardiomyopathy in the general population.

\section{ACKNOWLEDGEMENTS}

We thank Dr B Butti for technical support, and Drs S Paggi and S Pelucchi for helping with data and samples collection.

\section{Authors' affiliations}

L Valenti, P Dongiovanni, A L Fracanzani, L Carmagnola, S Fargion, Department of Internal Medicine, Ospedale Maggiore Policlinico IRCCS, Università degli Studi, Milan, Italy

D Conte, M Fraquelli, Department of Gastroenterology, Ospedale Maggiore Policlinico IRCCS, Università degli Studi, Milan, Italy A Piperno, Clinica Medica, Ospedale San Gerardo, Università MilanoBicocca, Monza, Italy

A Vergani, Ospedale San Luca IRCCS, Italy

C Gianni, Department of Laboratory Medicine, Istituto Tumori IRCCS, Milan, Italy

This study was supported by grants: COFIN 2002, FIRB 2002, FIRST 2002, IRCCS progetto a concorso 2003.

Conflict of interest: none declared

Correspondence to: Professor S Fargion, Department of Internal Medicine, Ospedale Maggiore Policlinico IRCCS, Università degli Studi, Pad Granelli, Via F Sforza 35, 20122 Milano, Italy; silvia.fargion@ unimi.it

Received 14 February 2004

Accepted for publication 1 June 2004

\section{REFERENCES}

1 Harrison SA, Bacon BR. Hereditary hemochromatosis: update for 2003. J Hepatol 2003;38(Suppl 1):14-23.

2 Powell LW, Summers KM, Board PG, Axelsen E, Webb S, Halliday JW. Expression of hemochromatosis in homozygous subjects. Implication for early diagnosis and prevention. Gastroenterology 1990;98:1625-32.

3 Feder JN, Gnirke A, Thomas W, Tsuchihashi Z, Ruddy DA, Basava A, Dormishian F, Domingo R Jr, Ellis MC, Fullan A, Hinton LM, Jones NL, Kimmel BE, Kronmal GS, Laver P, Lee VK, Loeb DB, Mapa FA, McClelland E, Meyer NC, Mintier GA, Moeller N, Moore T, Morikang E, Wolff RK, et al. A novel MHC class I-like gene is mutated in patients with hereditary hemochromatosis. Nat Genet 1996;13:399-408.

4 Olynyk JK, Cullen DJ, Aquilia S, Rossi E, Summerville L, Powell LW. A population-based study of the clinical expression of the hemochromatosis gene. N Engl J Med 1999;341:718-24.

5 Beutler E, Felitti VJ, Kozial JA, Ho NJ, Gelbart T. Low penetrance of the $845 \mathrm{G} \rightarrow \mathrm{A}$ (C282Y) HFE hereditary hemochromatosis mutation. Lancet 2001;359:211-18.

6 Cox T, Rochette J, Camaschella C, Walker A, Robson K. Clinical hemochromatosis in HFE mutation carriers. Lancet 2002;360:412.

7 McCune A, Worwood M. Penetrance in hereditary hemochromatosis. Blood 2003; 102:2696.

8 Lee PL, Gelbart T, West C, Halloran C, Felitti V, Beutler E. A study of genes that may modulate the expression of hereditary hemochromatosis: transferrin receptor-1, ferroportin, ceruloplasmin, ferritin light and heavy chains, iron regulatory proteins (IRP)- 1 and -2 , and hepcidin. Blood Cells Mol Dis $2001 ; 27: 783-802$.

9 Beutler E, Gelbart T. Tumor necrosis factor alpha promoter polymorphisms and liver abnormalities of homozygotes for the $845 \mathrm{G} \rightarrow \mathrm{A}$ (C282Y) hereditary hemochromatosis mutation. Blood 2002;100:2268-2269.

10 Fargion S, Valenti L, Dongiovanni P, Scaccabarozzi A, Fracanzani AL, Taioli E, Mattioli M, Sampietro M, Fiorelli G. Tumor necrosis factor alpha promoter polymorphisms influence the phenotypic expression of hereditary hemochromatosis. Blood 2001;97:3707-12.

11 Pietrangelo A. Iron oxidative stress and liver fibrogenesis. $J$ Hepatol 1998;28(Suppl 1):8-13.

12 Niemela O, Parkkila S, Britton RS, Brunt E, Janney C, Bacon BR. Hepatic lipid peroxidation in hereditary hemochromatosis and alcoholic liver injury. $J$ Lab Clin Med 1999;133:451-60.

13 Perez MJ, Cederbaum Al. Adenovirus mediated expression of $\mathrm{Cu} / \mathrm{Zn}$ - or $\mathrm{Mn}$ superoxide dismutase protects against CYP2E1-dependent toxicity. Hepatology 2003;38: $1146-58$.

14 Wheeler MD, Nakagami M, Bradford BU, Uesugi T, Mason RP, Connor HD, Dikalova A, Kadiiska M, Thurman RG. Overexpression of manganese superoxide dismutase prevents alcohol induced liver injury in the rat. J Biol Chem 2001;276:36664-72.

15 Li Y, Huang TT, Carlson EJ, Melov S, Ursell PC, Olson JL, Noble L, Yoshimura MP, Berger C, Chan PH. Dilated cardiomyopathy and neonatal lethality in mutant mice lacking manganese superoxide dismutase. Nat Genet 1995; 11:376-81.

16 Shimoda-Matsubayashi S, Matsumine H, Kobayashi T, Nakagawa-Attori Y, Shimizu Y, Mizuno Y. Structural dimorphism in the mitochondrial targeting sequence in the human manganese superoxide dismutase gene. Biochem Biophys Res Commun 1996;226:561-5.

17 Degoul F, Sutton A, Mansouri A, Cepanec C, Degott C, Fromenty B, Beaugrand $M$, Valla $D$, Pessayre $D$. Homozygosity for alanine in the mitochondrial targeting sequence of superoxide dismutase and risk for severe alcoholic liver disease. Gastroenterology 2001;120:1468-74.

18 Sutton A, Khoury H, Prip-Buus C, Cepanec C, Pessayre D, Degoul F. The Ala16Val genetic dimorphism modulates the import of human manganese 
superoxide dismutase into rat liver mitochondria. Pharmacogenetics 2003; 13:145-57

19 Fracanzani AL, Conte D, Fraquelli M, Taioli E, Mattioli M, Losco A, Fargion S. Increased cancer risk in a cohort of 230 patients with hereditary hemochromatosis in comparison to matched control patients with non ironrelated chronic liver disease. Hepatology 2001;33:647-51.

20 Barry M, Sherlock S. Measurement of liver iron concentration in needle biopsy specimens. Lancet 1971;1:100-3.

21 Sinigaglia L, Fargion S, Fracanzani AL, Binelli L, Battafarano N, Varenna M, Piperno A, Fiorelli G. Bone and joint involvement in genetic hemochromatosis: role of cirrhosis and iron overload. J Rheumatol 1997;24:1809-13.

22 Cecchetti G, Binda A, Piperno A, Nador F, Fargion S, Fiorelli G. Cardiac alterations in 36 consecutive patients with idiopathic haemochromatosis: polygraphic and echocardiographic evaluation. Eur Heart $J$ $1991 ; 12: 224-30$.

23 Richardson P, McKenna W, Bristow M, Maisch B, Mautner B, O'Connell J, Olsen E, Thiene G, Goodwin J, Gyarfas I, Martin I, Nordet P. Report of the 1995 World Health Organization/International Society and Federation of Cardiology Task Force on the Definition and Classification of Cardiomyopathies. Circulation 1996:93:841-2.

24 Muhlestein JB. Cardiac abnormalities in hemochromatosis. In: Barton JC Edwards CQ, eds. Hemochromatosis: genetic, pathophysiology, diagnosis and treatment. Cambridge, UK: Cambridge University Press, 2000:297-31 1

25 Camaschella C, Roetto A, Cali A, De Gobbi M, Garozzo G, Carella M, Majorano N, Totaro A, Gasparini P. The gene TFR2 is mutated in a new type of haemochromatosis mapping to 7q22. Nat Genet 2000;25:14-15.

26 Montosi G, Donovan A, Totaro A, Garuti C, Pignatti E, Cassanelli S, Trenor CC, Gasparini P, Andrews NC, Pietrangelo A. Autosomal-dominant hemochromatosis is associated with a mutation in the ferroportin (SLC11A3) gene. J Clin Invest 2001;108:619-23.
27 Piperno A, Sampietro M, Pietrangelo A, Arosio C, Lupica L, Montosi G, Vergani A, Fraquelli M, Girelli D, Pasquero P, Roetto A, Gasparini $P$ Fargion S, Conte D, Camaschella C. Heterogeneity of hemochromatosis in Italy. Gastroenterology 1998;114:996-1002.

28 Livesey KJ, Wimhurst VL, Carter K, Worwood M, Cadet E, Rochette J, Roberts AG, Pointon JJ, Merryweather-Clarke AT, Bassett ML, Jouanolle AM Mosser A, David V, Poulton J, Robson KJ. The 16189 variant of mitochondria DNA occurs more frequently in C282Y homozygotes with haemochromatosis than those without iron loading. J Med Genet 2004;41:6-10.

29 Pereira AC Cuoco MAR, Mota GF, da Silva F, Freitas HFG, Bocchi EA, Soler JMP, Mansur AJ, Krieger JE. Hemochromatosis gene variants in patients with cardiomyopathy. Am J Cardiol 2001;88:388-91.

30 Hetet G, Elbaz A, Gariepy J, Nicaud V, Arveiler D, Morrison C, Kee F, Evans A, Simon A, Amarenco P, Cambien F, Grandchamp B. Association studies between haemochromatosis gene mutations and the risk of cardiovascular diseases. Eur J Clin Invest 2001;31:382-8.

31 Turoczi T, Jun L, Cordis G, Morris JE, Maulik N, Stevens RG, Das DK. HFE mutation and dietary iron content interact to increase ischemia/reperfusion injury of the heart in mice. Circ Res 2003;92:1240-6.

32 Hiroi S, Harada H, Nishi H, Sato N, Nagai R, Kimura A. Polymorphisms in the SOD2 and HLA-DRB1 genes are associated with nonfamilial idiopathic dilated cardiomyopathy in Japanese. Biochem Biophys Res Commun 1999;261:332-9.

33 Miranda CJ, Makui $\mathrm{H}$, Soares RJ, Bilodeau M, Mui J, Vali $\mathrm{H}$, Bertrand R, Andrews NC, Santos MM. Hfe deficiency increases susceptibility to cardiotoxicity and exacerbates changes in iron metabolism induced by doxorubicin. Blood 2003;102:2574-80.

34 Hsiu-Chuan Y, Oberley TD, Vichitbandha S, Ho YS, St Clair DK. The protective role of manganese superoxide dismutase against adriamycininduced acute cardiac toxicity in transgenic mice. J Clin Invest 1996;98:1253-60.

\section{$\mathrm{ECHO}$}

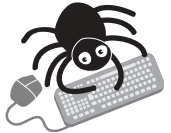

Please visit the Journal of Medical Genetics website [www. jmedgenet. com] for a link to the full text of this article.
Dynamic changes of gene expression profiles during postnatal development of the heart in mice

H-W Chen, S-L Yu, W-J Chen, P-C Yang, C-T Chien, H-Y Chou, H-N Li, K Peck, C-H Huang, F-Y Lin, J J W Chen, Y-T Lee

Objective: To study postnatal cardiac differentiation in the mouse.

Hypothesis: There might be mechanisms or factors in cardiac differentiation that could be identified by systematic gene expression analysis during postnatal cardiac development.

Methods: Expression of 6144 genes was examined in mouse heart, from the newborn period (day 0), through day 7 and day 14 , to adulthood, using the cDNA microarray approach. Northern blotting and immunohistochemical techniques were used to confirm the microarray results.

Results: Various cardiac development related genes involving the cell cycle (cyclin Bl, proliferating cell nuclear antigen (PCNA), and Ki67), growth factors (IGF-II, pleiotrophin (PTN), and midkine (MK)), and transcriptional regulation, cytoskeleton, and detoxification enzymes were identified by microarray analysis. Some of these genes were also confirmed by Northern blotting and immunohistochemistry of their RNA and protein content. In vivo treatment with PTN (20 ng/g) increased bromodeoxyuridine incorporation (by 2.24-fold) and PCNA expression (by 1.71-fold) during day 7 to day 14, indicating that PTN induces cell proliferation in mouse heart.

Conclusions: Global gene expression analysis in the whole heart may be useful in understanding the orchestrated process of postnatal development or terminal differentiation in the cardiac environment. These data are likely to be helpful in studying developmental anomalies of the heart in neonates.

A Heart 2004;90:927-934. 